\title{
Correction to: Astaxanthin-loaded polymer-lipid hybrid nanoparticles (ATX-LPN): assessment of potential otoprotective effects
}

Jiayi Gu $u^{1,2,3+}$, Yuming Chen ${ }^{1,2,3+}$, Ling Tong ${ }^{1,2,3}$, Xueling Wang ${ }^{1,2,3^{*}}$, Dehong $Y u^{1,2,3^{*}}$ and Hao Wu $u^{1,2,3^{*}}$

\section{Correction to: J Nanobiotechnol (2020) 18:53}

https://doi.org/10.1186/s12951-020-00600-x

Following publication of the original article [1], the authors identified errors in Fig. 8d and f. The corrected

Fig. 8 and the corrected figure caption are given below.

*Correspondence: xuelingwang2013@163.com; dehongyu@126.com;

wuhao@sh9hospital.org

${ }^{\dagger}$ Jiayi Gu, Yuming Chen are co-First authors

1 Department of Otolaryngology-Head and Neck Surgery, Shanghai Ninth

People's Hospital, Shanghai Jiao Tong University, School of Medicine,

Shanghai 200011, China

Full list of author information is available at the end of the article

(c) The Author(s) 2020. This article is licensed under a Creative Commons Attribution 4.0 International License, which permits use, sharing, adaptation, distribution and reproduction in any medium or format, as long as you give appropriate credit to the original author(s) and the source, provide a link to the Creative Commons licence, and indicate if changes were made. The images or other third party material in this article are included in the article's Creative Commons licence, unless indicated otherwise in a credit line to the material. If material is not included in the article's Creative Commons licence and your intended use is not permitted by statutory regulation or exceeds the permitted use, you will need to obtain permission directly from the copyright holder. To view a copy of this licence, visit http://creativeco mmons.org/licenses/by/4.0/. The Creative Commons Public Domain Dedication waiver (http://creativecommons.org/publicdomain/ zero/1.0/) applies to the data made available in this article, unless otherwise stated in a credit line to the data. 
a
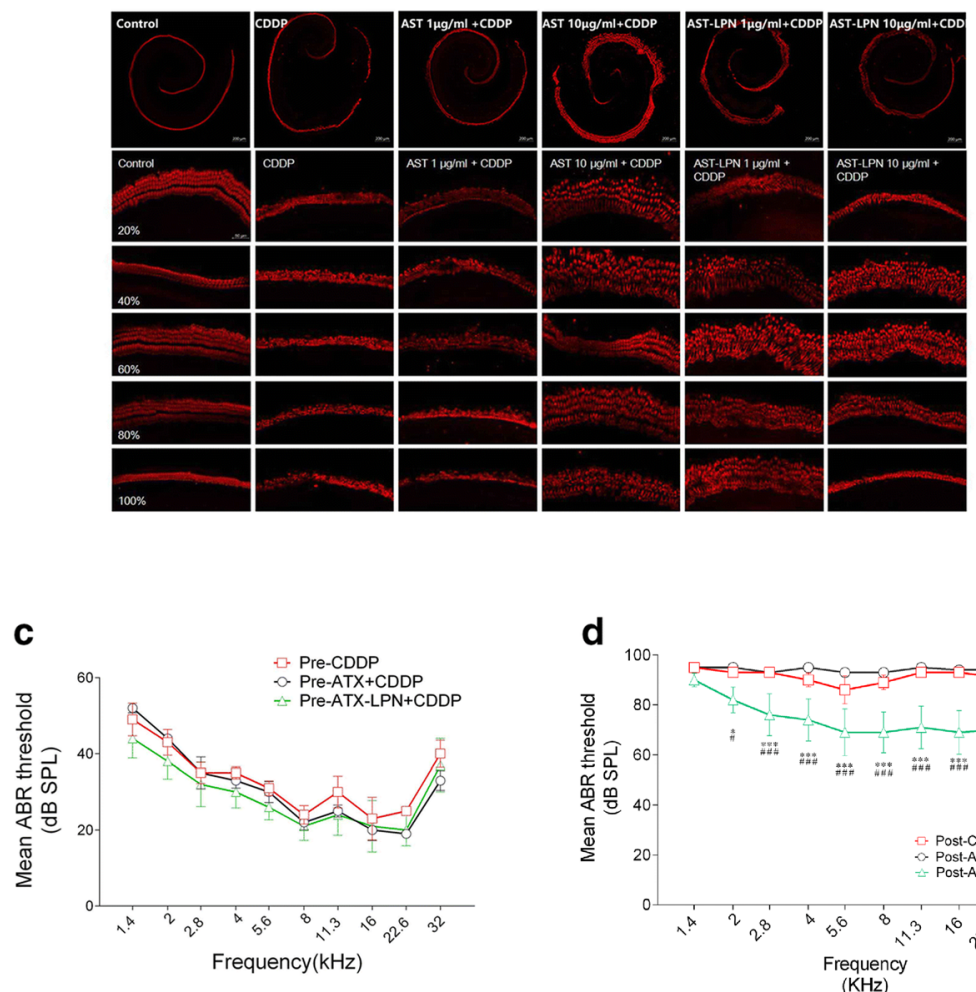

f

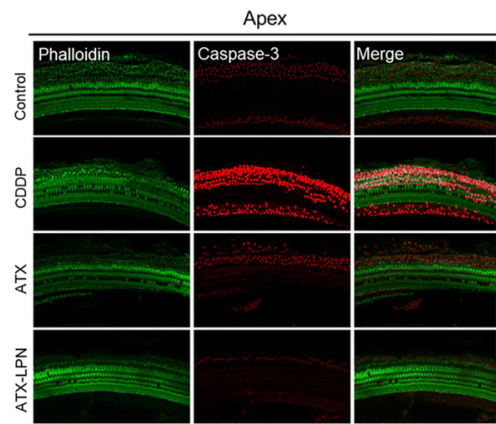

d

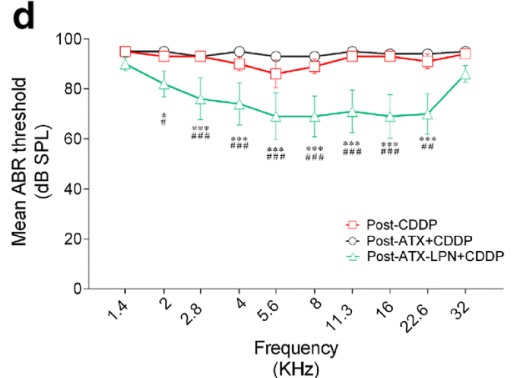

$\mathrm{KHz})$

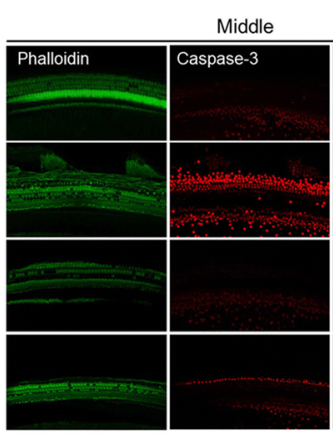

b

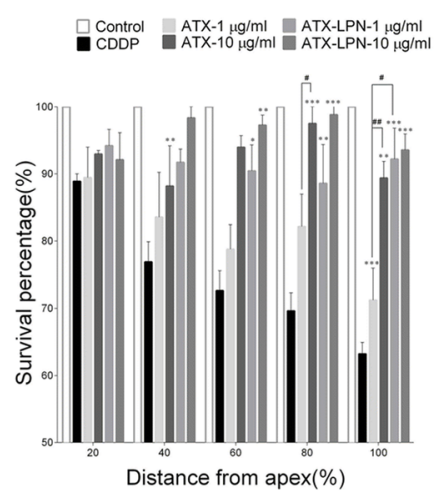

$\begin{array}{lll} & \square \text { Control } & \\ & & \\ & - \text { CDDP } & \text { \#:ATX-LPN/ATX:Control } \\ & - \text { ATX } & \text { *:ATX-LPN/ATX:CDDP } \\ & \nabla \text { ATX-LPN } & \text { \&:ATX-LPN:ATX }\end{array}$

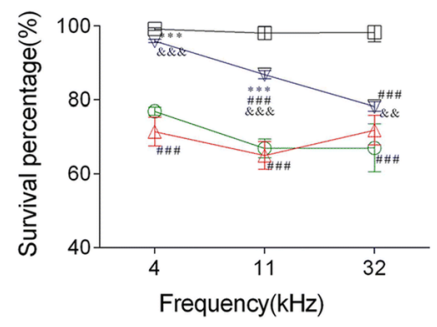

Fig. 8 ATX-LPN partially rescue CDDP-induced hearing loss. a In vitro culture of Organ of Corti. CDDP induced a significant loss of hair cells (Myosin VII, red), especially in the high-frequency areas. b Survival outer hair cell numbers in $1 \mathrm{~mm}$ length at different locations from apical end of each group. ${ }^{*} p<0.05,{ }^{* *} p<0.01,{ }^{* * *} p<0.001$ as compared with CDDP, ${ }^{*} p<0.05$ as compared with ATX + CDDP. c-e Mean ABR threshold of mice treated with cisplatin, ATX $1 \mathrm{mg} / \mathrm{ml}, 5 \mu \mathrm{l}$. ATX-LPN + CDDP. ${ }^{*} p<0.05,{ }^{* *} p<0.01,{ }^{* * *} p<0.001$ as compared with CDDP, $p<0.05$ as compared with ATX + CDDP. $\mathbf{f} /$ mmunohistochemistry of cochlea in apex/middle/basal area of BM. The pretreatment of protective drugs (ATX/ATX-LPN) effectively reduced the expression of caspase-3 (red fluorescence) and rescued more OHCs (green fluorescence)

\section{Author details}

${ }^{1}$ Department of Otolaryngology-Head and Neck Surgery, Shanghai Ninth People's Hospital, Shanghai Jiao Tong University, School of Medicine, Shanghai 200011, China. ${ }^{2}$ Ear Institute, Shanghai Jiao Tong University, School of Medicine, Shanghai 200011, China. ${ }^{3}$ Shanghai Key Laboratory of Translational Medicine On Ear and Nose Diseases (14DZ2260300), Shanghai 200011, China.

Published online: 19 May 2020

\section{Reference}

1. Gu J, Chen Y, Tong L, Wang X, Yu D, Wu H. Astaxanthin-loaded polymerlipid hybrid nanoparticles (ATX-LPN): assessment of potential otoprotective effects. J Nanobiotechnol. 2020;18:53. https://doi.org/10.1186/s1295 $1-020-00600-x$.

\section{Publisher's Note}

Springer Nature remains neutral with regard to jurisdictional claims in published maps and institutional affiliations. 